\title{
Culture Development Planning in the Special Region of Yogyakarta (Management Planning of Cultural Heritage in Kotagede District based on Community Empowerment Conservation Model)
}

\author{
Eko Suryanti $^{1,2^{*}}$, Sumartono ${ }^{3}$, Hermawan $^{3}$ \\ ${ }^{1}$ Master Program of Public Administration, Faculty of Administrative Sciences, University of Brawijaya, Malang \\ ${ }^{2}$ Department of Regional Development Planning, Yogyakarta \\ ${ }^{3}$ Graduate Program, Faculty of Administratives Sciences, University of Brawijaya, Malang
}

\begin{abstract}
The Special Region of Yogyakarta is a cultural rich city with excellent cultural resources. Yogyakarta should manage their assets with long-term planning to keep the sustainability. There is a very unique planning process due to a combination of political, technocratic, participatory, top down and bottom up approaches. This planning process is comprehensive or integrated because its involved many actor from multisectoral, multidisciplinary, multi regulatory, and multi planning documents, etc. Local wisdoms have been coloring the planning documents. This study describe and analyze the cultural development planning in Yogyakarta especially on the Management Planning in Kotagede Cultural Heritage District. We used qualitative descriptive approach methods and Miles and Huberman analysis methods. Participation of community and Non Governmental Organization (NGO) in conservation planning of cultural heritage in this area is very significant in simplify the government task because people have been more literate in planning, have database of cultural assets, and capable of making their own decisions for the future of the region. Participatory rural appraisal (PRA) dan Rapid Rural Appraisal (RRA) were integrated in the planning process of Kotagede Heritage District management, thus it becomes a model of cultural heritage with community empowerment-based conservation.
\end{abstract}

Keywords: culture development planning, comprehensive planning, heritage cultural district, community empowerment-based conservation.

\section{INTRODUCTION}

Recent day's people should be in the circlet of changes in all sectors triggered by globalization, modernization, urbanization, industrialization/ capitalization. The changes have brought acculturation and dependence that was not synchronized with the cultural resistance, thus it narrows the national identity [1]. The impact of were eviction, over-functioned, and demolition of historic building in the city and it's very conspicuous in capitalist industrialized countries $[2,3]$.

A strategy for cultural resources conservation was proposed to face the process of changes on cultural sector in the planning documents. It was expected to ensure a comprehensive and coordinated approach from the concept of national policies to the implementation and its follow-up [4]. Culture should be included in the development strategy thus the cultural assets can be saved and used in the regional development. Development that ignores the wisdom of traditions and cultural values of the

\footnotetext{
* Correspondence address:

Eko Suryanti

Email : ekosuryanti@yahoo.co.id

Address : Master Program of Public Administration, Faculty of Administrative Science, University of Brawijaya, Jl. Mayjen Haryono 163 Malang 65145
}

local community will face problems, due to the lack of attention to the social-cultural dimension that became public behavior frame of the community [5].

Culture contribute to the achievement of sustainable development with environmental conservation; improving income of community as embodied in the Millenium Development Goals. Culture industry has undoubtedly become a public need and affect the economic growth and quality of life. Cultural industries provide a creative space for the public, to protect and preserve the cultural diversity, employment, and increasing national or regional revenue $[6,7]$.

Some countries have efforts to protect their old buildings, e.g. Australia, Japan (Kyoto and Nara), Korea, England, France, and Italy. Thus the settings of building permits are very strict and the facade suitability is carefully concerned. On the contrary, this is not strictly applicable in Indonesia [4].

During this time, the culture and civilization problem is less of concern, however, we should consider that no civilization means no nation. As a result, the evolution of society is dominated by external forces instead of internal motivation and spiritual aspirations. It makes communities to be isolated [5]. Sometimes areas of cultural 
conservation were neglected due to physical and economic development [8].

Culture-based approach is an oldest approach model and predominantly used in the planning process of nation development. The cultural approach in development should be interpreted not as a means of social engineering, but primarily to find sources of strength in the local culture [5].

Some efforts proposed for recognizing the importance of cultural assets in the Special Region of Yogyakarta. The conservation efforts have been made through the protection and the rescue from destruction, monuments extinction, buildings, also its surroundings and prevent it from further danger. Conservation is also an attempt to maintain the existence of historical and archaeological heritage with its values through management that includes protection, development and utilization. Management is also pursued by the way of planning, implementation and evaluation on an ongoing basis. Protection requires rescue acts, zoning, maintenance and restoration (consolidation, conservation, rehabilitation, reconstruction, renovation) $[9,10]$.

The objectives of the study are : 1) identify and describe the planning process of cultural development especially the management planning of Kotagede cultural heritage district; 2) identify and describe the accomodated aspects in the planning documents; 3 ) construct the cultural heritage conservation planning model which based on the community empowerment.

\section{Management of Heritage Area}

The management of a heritage area is highly vulnerable and face a severe global scale changes, thus the planning of regional development should be culture-based to be significant in the development of the area. Socio-cultural changes without the support of a superior planning which considering the aspects of internal, social and economic growth leading to greater resilience of culture and prosperity in the area of cultural heritage. The efforts of regional development should be conducted in a more effective and efficient way by combining the regional and sectoral aspects to be successful. Revitalization of cultural heritage area can be pursued in an integrated development model $[11,12]$. Integrated management of cultural heritage area will prevent intervention inaccuracies [4].

It should be understood by all stakeholders that the cultural management plan is not just the domain of cultural institution, but also other sectors in a network $[3,12]$. The government's inability to control the activities performed in different levels of government and private sector will complicate the efforts to conserve the protected areas. Involving the community in the phase of planning, implementation and monitoring will ensure the sustainability of programs and activities that have been planned by the stakeholders because they are entrusted $[13,14]$.

Development planning is influenced by three factors: 1) the ability of local governments to fund the development plan, 2) community involvement in the development process, 3 ) the commitment on the results of the development and planned development targets [15].

The approach of 'down to earth' and people as center of development is strongly appropriate to meet the needs of cultural heritage conservation and needs of the political, social and economic development [10].

\section{Cultural Heritage in Yogyakarta}

Integrated planning in the Special Region of Yogyakarta must consider that Yogyakarta is a cultural city with excellent cultural prehistory resources, e.g. Ancient Mataram, Islamic Mataram, Yogyakarta Palace, and contemporary culture, that designed to be the cultural center. Yogyakarta have origin history in Kotagede, as the capital of Islamic Mataram Kingdom for the first time of its establishment. Kotagede is rich with cultural resources such as King Thombs, Mosques, Traditional Houses, Silver Handycraft, Tolerance Alley, Traditional Market, Moat, city wall, city square, granary, etc $[16,25]$.

Depreciation on the cultural heritage of Kotagede Heritage District continues to occur due to various causes, e.g. incomprehension, unwillingness and inability to maintain the inheritance; incorrect maintenance actions, lack of sinergy in cross sectoral development, weak law enforcement on natural processes. An example is earthquake in May $27^{\text {th }}, 2006$ that destroyed the heritage building, thus need a long time restoration planning. Moreover, the problem become more complex related to the infrastructure, traffict, handycraft industry, tourism, art, multi-actors, regulation enforcement, relationship scenario, and the shrinkage of tangible and intangible heritage $[10,17]$.

Kotagede is not the only target of government institution. Not all resources have the same level on the understanding and 
awareness towards the concept and planning of culture, especially Kotagede. Planning performance is still weak, specifically in the competence of human resources, updating and validity data and information, coordination and syncronization amongs systems, establishment regulations, concepts understanding on conservation and planning, which is often partial or overlapping [18].

\section{Theory on Regional Planning}

The regional planning is a process of determination phases to manage the region's resources for people welfare. It comprises of data and information processing, analysis of existing condition and problems, plan's frame and budgeting, policy, sectoral planning, government function distribution, regional plan, work plan (program, activities, budgeting), stabilization of policy, communication of actors, controlling and evaluation, implementation review, and estimation. Development planning use multiple approaches, i.e. technocratic, participatory, political, top down and bottom-up $[19,20,21,22]$.

Planning is a part of modern public management. There are seven function of public management, i.e. planning, organizing, staffing, directing, coordinating, reporting, and budgeting [23].

\section{MATERIALS AND METHODS}

This research is descriptive qualitative with focus on the planning process of cultural development in Special Region of Yogyakarta, especially management planning of Kotagede cultural heritage district. The aspects were accomodated by the planning documents, the cultural heritage conservation model based on community empowerment. Site of research is in Kotagede Cultural Heritage District, Special Region of Yogyakarta.

\section{Data Collection and Analysis}

Data sourced from the informant, events and documents through in-depth interviews, observation and technical documentation. Indepth interviews were conducted to the planners, implementors, supervisors and evaluators regards to the infrastructure, culture, crosssectoral aspects. The respondents were come from government, NGO, community, academic, and culturalist. Documentation were taken from some documents regards to Special Region of Yogyakarta and Kotagede, such as regional planning, regulation, books, letters, reports, etc. We observed some events like festival, discussions, cultural dialogues, data entry to www.jogjaplan.com, and priority selecting forum.

Analysis methods used interactive model of Miles and Huberman. The research phases are data collection, data reduction, data presentation, drawing and testing conclusions. Test of data validity using the technique of credibility, transferability, auditability (dipendability), confirmability and triangulation [24].

\section{RESULTS AND DISCUSSION \\ Cultural Resources of Yogyakarta}

Special Region of Yogyakarta as a special province in Indonesia is a Kingdom, that Dutch named it as Vorstenlanden and Japan called it as Kooti. It is located between Mount Merapi and South Coast of Central Java, which is believed to laid on the imaginary axis between Merapi to South Coast. The assosiative cultural landscape of this region were the result of creativity, taste, intention, and the work of the ancestors in prehistoric times, ancient Mataram, Islamic Mataram, Colonial Dutch and contemporary product. Yogyakarta's culture contains a lot of value of struggle/heroism, cultural heritage, leadership/governance, livelihood, language, spatial planning and architecture, art, technology, customs and traditions $[25,26,27]$.

Special Region of Yogyakarta originated from Islamic Mataram with first capital in Kotagede, thus Kotagede has strategic value for realizing the renaissance and functioned as cultural center. Kotagede located at $6 \mathrm{~km}$ southeast of the province's capital city, situated between Gajah Wong River and Manggisan River, in two administration planning area, Bantul Regency and Yogyakarta City [16, 28].

Kotagede is not administrative nomenclature, but it is a cultural entity that consisted of five villages, i.e. Purbayan, Prenggan, Rejowinangun, Jagalan and Singosaren. Kotagede designated as a heritage area within the provincial authority by the Governor Decision No. 186/2011, due to the policy gaps between Kota Gede under the Bantul Regency and Yogyakarta City [28].

Kota Gede initial character is the center of governance, economic, social, and religious activities with royal city planning. It was characterized by four unity components, which is identical to catur gatra tunggal that normally exist in the centers of Islamic empire in the $16^{\text {th }}$ Century. It consisted of Palace, Square, Mosque and Market as relationship symbol with God, 
universe, and people of the world $[16,17,28]$. The following is the cultural resources in Kota Gede today (Table 1 and Fig. 1).

Table 1. Cultural Resources Based on Spacial Character

\begin{tabular}{ll}
\hline \multicolumn{1}{c}{ Character } & \multicolumn{1}{c}{ Cultural Resources } \\
\hline $\begin{array}{l}\text { Centre of Kingdom } \\
\text { and Pilgrimages }\end{array}$ & $\begin{array}{l}\text { Great Mosque, Thomb of the Kings } \\
\text { and the Knights, Spring of Selirang, } \\
\text { Market, Sites of Dalem, Cantheng } \\
\text { Watu, Topo-nymy of square, Spacial } \\
\text { Structural of Java City Centre. }\end{array}$ \\
City of craftmens and & $\begin{array}{l}\text { Java Traditional Houses with } \\
\text { distinctive characteristics and very } \\
\text { high density in the core area. }\end{array}$ \\
City of Commerce & $\begin{array}{l}\text { The houses of the skipper with } \\
\text { typical eclectic style that is formed } \\
\text { as independent building }\end{array}$ \\
City of Religious & $\begin{array}{l}\text { Development centre of religious } \\
\text { activities and religious leaders } \\
\text { occupancy }\end{array}$ \\
City of tourism & Buildings for silver \\
gallery/showroom & Mass settlement in the suburbs \\
Contemporary city & \\
\hline
\end{tabular}

Source : [29]

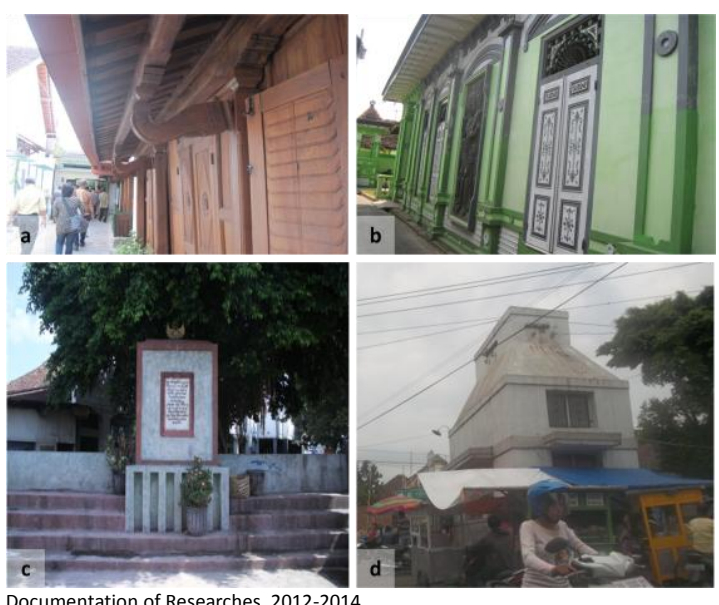

Figure 1. Cultural Resources in Kotagede Description:
a. Alley
c. Pacak Suji
b. Kalang House Harmony d. Babon Anim

\section{Planning Process of Culture Development}

All sectors of development was directed to regard Special Region of Yogyakarta as cultural center and Yogyakarta Rennaisance. Region cultural development planning will contribute to national cultural development. It directed to realize cultured, ethical, and civilized human resources based on Pancasila, competitive nation, as well as beautiful and sustainable Indonesia. This region cultural development planning also contribute to the national development goal, to gain sustainable and developed communities' income. It is because the cultural heritage related with the creative industry that produce many benefits for the state and nation [30].

Cultural heritage is mentioned in many planning document, because Yogyakarta has five privilege authority in filling the position of Governor and Vice Governor, culture, institution, spatial lay out, and agrarian by Indonesia Law No. $13 / 2012$.

Ethics movement of cultural heritage conservation initiated by international institutions or personal repercussions towards Indonesia. Thus, established Indonesian cultural heritage institutions such as Jogja Heritage Society, Centre of Heritage Conservation, Cultural Studies Center of Gadjah Mada University, Kanthil Foundation, Centre for Documentation, Joglo Forum, Senthir, JMBN, etc. The foreign organization that supported Yogyakarta Region especially Kotagede are JICA, JRF, ICOMOS, UNESCO, IOM, and World Bank [18].

NGO always move to courage government, donator, and community to participate in the cultural conservation efforts, especially in Yogyakarta and Kotagede. NGO consider cultural assets of Yogyakarta and Kotagede is very unique and rich, consists of cultural heritage, natural heritage, and a blend of natural and cultural heritage.

Cultural Planning process has being led by Cultural Agency supported by Public Work Agency and many stakeholders. Cultural Agency need to gather some stakeholders and shareholders to collect some data and information about their need and interest in the cultural development. The gathering was also beneficial for the synchronization, sharpening, and coordination to avoid overlapping in the development planning.

After this process, Cultural Agency conducted internal coordination with all of the units in the agency to follow up the result of stakeholders and shareholders meeting in cultural planning draft. This draft then integrated with all sectors in region development planning led by the Department of Regional Development Planning. The draft from cultural agency was integrated in the longterm, midterm, and shortterm planning. If the cultural plannings were cross sectoral, it must be handled by the Department of Regional Development Planning, especially for Kotagede privilege planning (culture and spatial).

Five years planning need syncronization between midterm region planning with midterm 
cultural agency planning, or strategic planning with national plan. Draft on strategic plan of Cultural Agency is used as an improvement design of Midterm Regional Planning. A shortterm planning also syncronized between Local Government Work Plan (RKPD) and Cultural Agency Work Plan (Renja SKPD), also its contribution to national program.

After processed by the Cultural Agency, the draft integrated in the Department of Regional Development Planning. For example, drafting regional work plan begins from data and information processing, and continued by analysis to a general overview in economic and financial area. Next phase was to evaluate the last year performance, review on national government policy and main ideas of Yogyakarta Region Parliament. Furthermore, they formulate the development problems, proposed the framework of economic and financial policies, priorities, goals and indicative platform, program and its priorities. They also established public consultation forums, alignment the priority of program plan and indicative platform [30].

Plan drafting is a design refinement process of initial draft into work plan draft based on the results of workplan verification on cultural institution. Verification was essential to integrate the programs, activities, performance indicators and indicative funds. The initial planning draft is presented systematically at least as follows:

1) introduction

2) evaluation on last year planning implementation

3) design of the regional economic and funding framework

4) priorities and targets

5) priority and program planning areas

\section{Development Planning Discussion}

Musrenbang (development planning discussion) is a long enough processes and stages for sharpening, alignment, clarification and agreement on the short planning draft. It was aimed to merge Musrenbang and the results of cultural sector forum; integrate the sectors. It also held a joint agreement among sectors' institution in Trilateral Forum in Department of Regional Development Planning regard to the activities sharing.

Formulation of the final draft need the Musrenbang work plan agreement. Finally, the Work Plan of Local Government defined by Regulation. This agreement was expected to keep the alignment between the central and regional planning.

Kotagede Cultural Heritage District community has been literate in planning. Their process was accompanied by Java Reconstruction Fund trough several steps as follows (Tabel 2).

Table 2. Cultural Heritage Conservation Planning in Kotaged

\begin{tabular}{ll}
\hline No. & Phases \\
\hline 1 & Understanding the management planning \\
2 & $\begin{array}{l}\text { Socialization to the level of district and urban/rural } \\
\text { actors }\end{array}$ \\
3 & $\begin{array}{l}\text { Coordination and consultation to the provincial/ } \\
\text { city/regency }\end{array}$ \\
4 & $\begin{array}{l}\text { Meetings of village consultation and outreach of } \\
\text { planning }\end{array}$ \\
5 & $\begin{array}{l}\text { Spatial and other rules assessment } \\
\text { Mapping of self help community (physical environ- }\end{array}$ \\
7 & $\begin{array}{l}\text { Cultural asset inventory (green maps and block-based } \\
\text { map planning) }\end{array}$ \\
9 & $\begin{array}{l}\text { Analysis of core zone } \\
\text { Formulate the reconstruction rehab plan and social } \\
10\end{array}$ \\
environmental management plan \\
Selection of priority plan
\end{tabular}

Source: [31]

The stages of each planning process are not much different. They collect data and information from many resources, then analysis the planning area overview, financial management and funding framework. Next, formulate the regional cultural development issues, strategic issues, SWOT analysis, explanation of vision, mission, goals and objectives, strategy and policy direction, indicative program with funding priorities, and establishment of local performance indicators.

The planning process appears to have been applying modern management theory of Gulick [23] called POSDCORB which consisted of planning, organizing, staffing, directing, coordinating, reporting and budgeting. Cultural planning process also through the stages of organize all related stakeholders, distribution of task which appropiate with the regulation. There are meeting between bottom up and top down direction from upper government and upper regulation. All of the planning process will be reported to the upper manager, government, 
and the community. Budgeting alocation also become a main part of planning because cultural development in an area will need great cost.

\section{Regulation and Plans on the Cultural Heritage}

All of process have been appropriate with Regulation from Ministry of Internal Affair No. $54 / 2010$ as derivative of Laws No. 25/2004 and Government Regulation No. 8/2008. All of the phases also implicate the planning theory of Conyers [22], Djunaedi [19], Nugroho and Wrihatnolo [20], and Tjokroamidjojo [21]. It is included not just the phases, but also what must be accomodated in the document, such as overview of planning area, estimation, program and activities planning.

Cultural development planning had goal to preserve and save all cultural asset, nation competitive, nation identity, and people prosperity based on Law No. 11/2010 about Cultural Heritage. It is also described in the Regional Regulation No. 6/2012 about Cultural Heritage Conservation and Governor Regulation No. 186/2010 about determination of Cultural Heritage District as derivative of the Regional Regulation.

Planning the development of culture in Special Region of Yogyakarta, especially Kotagede combines many affairs, many norms, ideals of conservation and development planning and budgeting. The application of spatial planning was synergy with each other but sometimes not.
Department of Regional Development Planning (BAPPEDA DIY) has generated long-term (RPJPD), mid-term (RPJMD) and short-term $(R K P D)$ regional development planning. BAPPEDA $D I Y$ also produced Action Plan for Stabilization on the Special Region of Yogyakarta as Cultural Center, Action Plan of Heritage District, Action Plan of Integrated Management for Kotagede Cultural Heritage District.

Planning process by Cultural Agency have resulted Cultural Agency Strategic Planning and Short Term Cultural Agency Work Plan. This agency also have produced sub sector planning document, i.e. Grand Strategy of Cultural Resistance, Kotagede Master Plan, Cultural Village Action Plan, etc. The planning of City Government was resulted Action Plan of Heritage City. Publics Works Agency has resulted Building and Environment Lay Out Plan, Detail Engineering Designs, and Drainage Master Plan. Comprehensive Kotagede Planning has produced by all actors based on their function in the management organization.

Community of Kotagede have produced Action Plan of Kotagede Heritage Management and Conservation, Community Settlement Plan by village through participatory rural appraisal (PRA) and rapid rural appraisal (RRA) as mentioned in Sumpeno [11] as approaches on integrated village planning. The integrated planning process in Yogyakarta's culture will form a pattern as follows (Fig. 2).

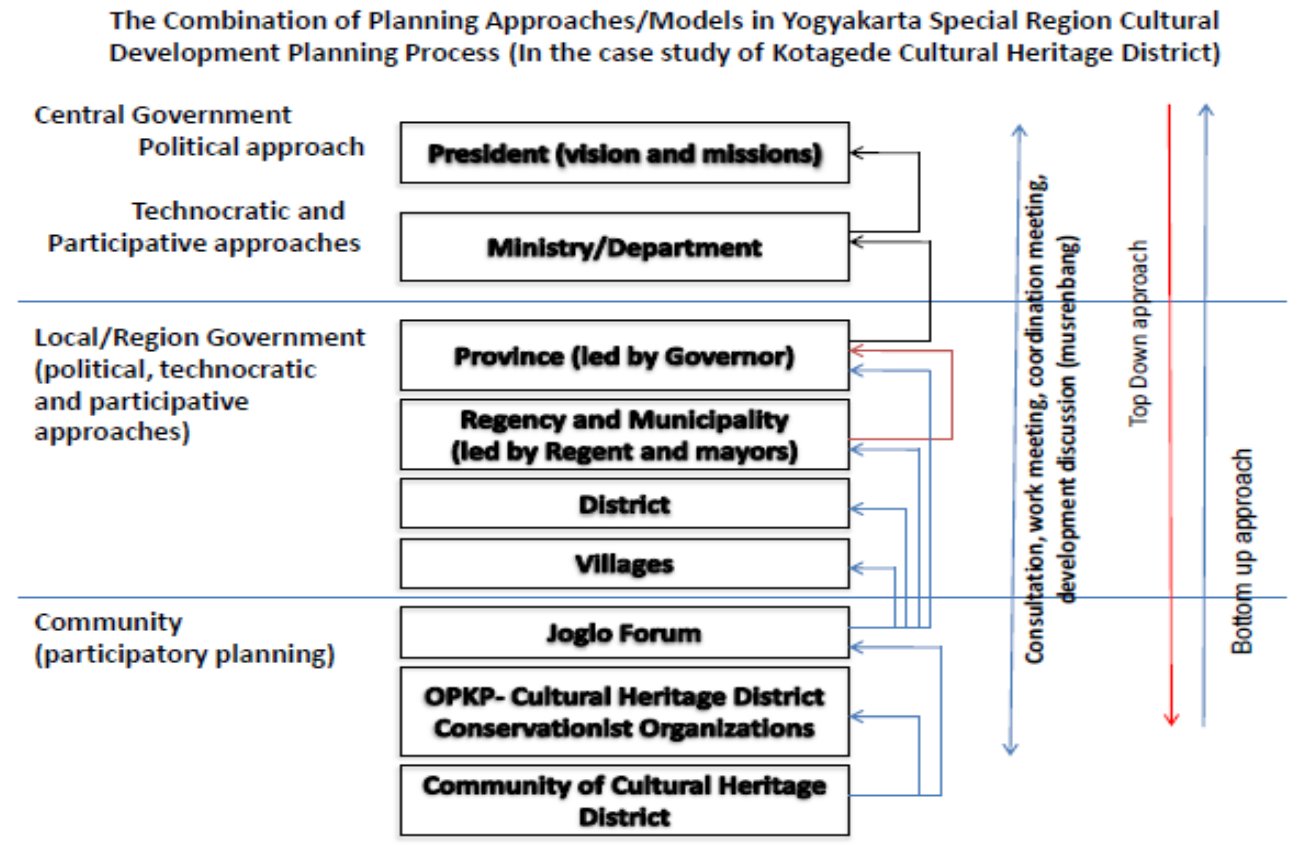

Figure 2. Integrated Development Planning Process in Yogyakarta 
Accomadated Aspects in Planning Documents Local wisdom of the regional culture is fundamental philosophy for planning and has included in the documents as mentioned follows (Table 3).

Table 2. Local Wisdom as Philosophy in Yogyakarta

\begin{tabular}{ll}
\hline \multicolumn{1}{c}{ Local Wisdom } & \multicolumn{1}{c}{ Interpretation } \\
bawono & $\begin{array}{l}\text { effort to save and beautify the } \\
\text { world }\end{array}$ \\
\hline $\begin{array}{l}\text { Gemah ripah loh jinawi } \\
\text { Sawiji greget sengguh ora } \\
\text { mingkuh }\end{array}$ & $\begin{array}{l}\text { Prosperous society } \\
\text { spirit to work hard and } \\
\text { responsibility }\end{array}$ \\
ratur gatra tunggal & $\begin{array}{l}\text { relation symbol of King with } \\
\text { politics, social, economic, } \\
\text { religion }\end{array}$ \\
Sangkan Paraning Dumadi & $\begin{array}{l}\text { God as the origin of man and } \\
\text { their culture }\end{array}$ \\
molong gilig & $\begin{array}{l}\text { merging of the ruler and the } \\
\text { people for development }\end{array}$ \\
Musyawarah/Rembugan & $\begin{array}{l}\text { a form of discussion based on } \\
\text { family spirit }\end{array}$ \\
Gotong Royong & working something together \\
Tepa selira & tolerant
\end{tabular}

The aspects that accomadated in some cultural documents in Yogyakarta and Kotagede are normative aspect, syncronization among documents, general conditions, the problems of conservation and management, integration with spatial regulation, vision, mision, goals, strategy, targets, program and activities plan, budgeting planning, implementator scenario, and agenda of policy. This aspects has schemed by Conyers [22], Nugroho and Wrihatnolo [20], Tjokroamidjojo [21].

Java Reconstruction Fund facilitated Kotagede planning document. They accomodated the documents related to disaster management, investation program plan, women empowerment, heritage conservation, infrastructure, environment, education and poverty.

Integrated Revitalization Masterplan of Kotagede Heritage Dictrict consist of review on juridical aspect, condition of Kotagede, institution plan, vision, mision, strategy, policy, and community empowerment in Kotagede conservation. The policy related to cultural heritage conservation, city's characters strengthening, tourism, infrastructure, institutional, traffict management, handycraft industry, and art performance. Integrated networks by sectors, department, agencies, units, actors, and resources of funding also has recommended by Sumpeno [11] and Branch [12].
Resources of the funding come from central and local government, and NGO, e.g. JRF, GMU, JICA, and World Bank. Although the funding for cultural development is overflow, it doesn't made cultural activities in Kotagede and the entire area in this region can be planned. Especially after Law No. 13/2012 established. The investors fears about the law, which inhibit the planning.

Programs of cultural planning which referred to the existed law are Culture Values Development, Culture Richness Management, Culture Diversity Management, Cooperation in Culture Management, Culture Facilities and Infrastructure improvement. Many activities in each program is bottom up proposals or top down directions.

Haris [15] explained that development planning is influenced by the ability of local government funding, community involvement, and the commitment to the plannings. For this cases, heritage conservation will need great cost, and also will need strong leaderships of street civil servants, good governance, independent soul, skill, and dare to risk. Planning sustainability need community participation and consistents with commitments in plannings.

\section{Heritage Conservation based on Community Empowerment}

Kotagede Community is a conservation model that has been ready to manage and preserve their district because they have data and information, some planning, and community institutions. The community participates in the phase of planning, implementation and controlling. They consult to the local government (planning dept., cultural agency), central government (heritage preservation agency, archeology agency, and ministry of public work) to integrate the development and conservation.

Some NGO like JRF, JHS, CHC and its networks did facilitate in donating, data collecting, planning, institutional strengthening, and expanding of networks after earthquake on May $27^{\text {th }}, 2006$ in Kotagede.

Currently, Kotagede community has some web or online information regard to their cultural heritage, i.e. www.kotagedeheritage.org, http:// kotagedelib.com, https://www.facebook.com/ Perpustakaan-Heritage-Kotagede that created privately or collective. Kotagede also has library that useful for planning and research, and people will get information about this library by accessing the website (Fig. 3). 


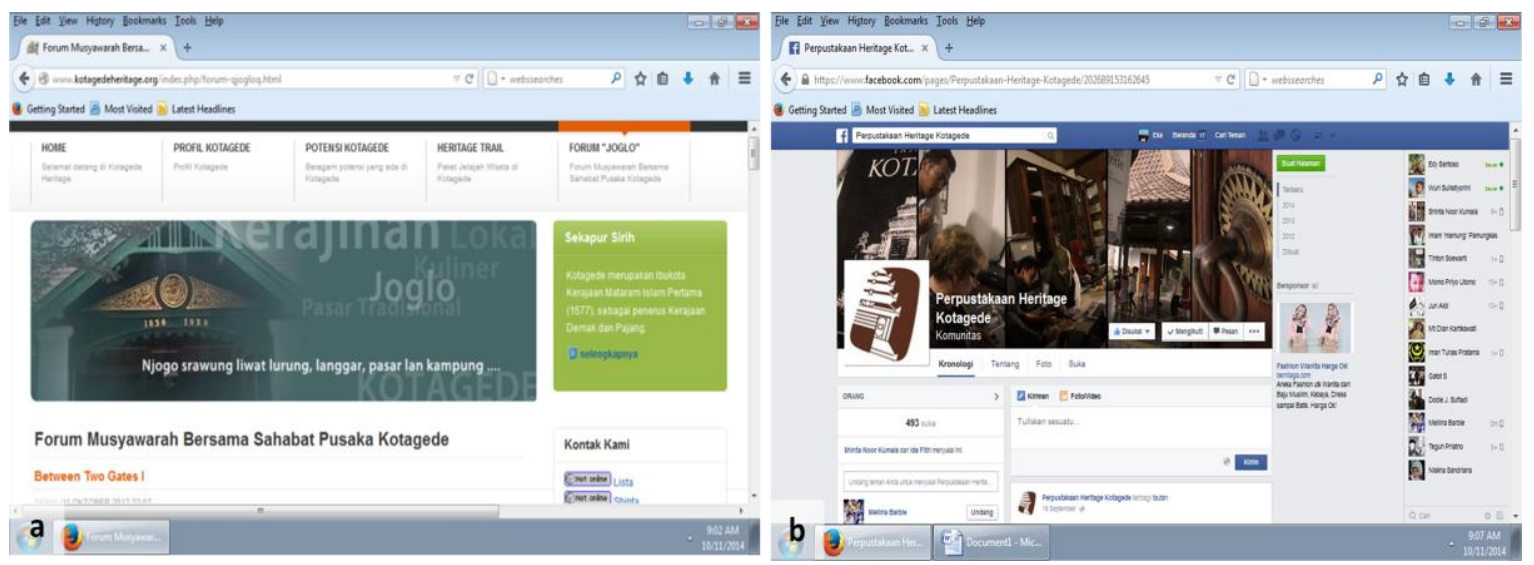

Figure 3. e-cultural heritage conservation of Kotagede

Description: a. web of Kotagede Heritage; b. Facebook page of Kotagede Heritage Library.

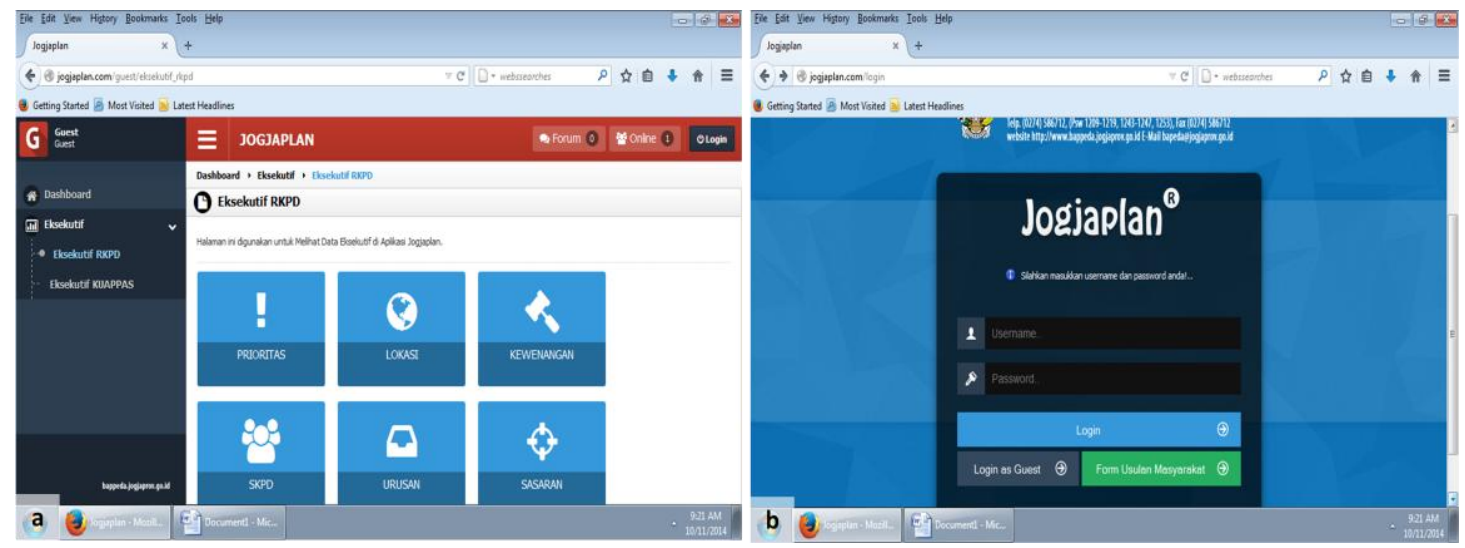

Figure 4. e-participatory planning in regular and special authority of regional development planning Description: a. web of jogjaplan; b. log in page for jogjaplan

Planning process in this district also groupbased in each villages, as like Abilawa, Mandaraka, Singosari, Binangun, Purbatilas, BKM and Joglo Forum. However, before the earthquake, Kotagede still have many conservation organizations such as Kanthil Foundation, Pusdok, Living Museum and OPKP Kotagede. At the time, fragmentation of the community becomes a threat for planning.

The government of Yogyakarta Special Region provides opportunity for local community to give their input into the planning process by accessing the www.jogjaplan.com (Fig. 4). Unfortunately, not all people in Yogyakarta including Kotagede can access and use the internet technology, thus the advantage of the webiste is limited to certain internet aware community.

\section{CONCLUSION}

Development planning regard to the cultural heritage of Yogyakarta integrate the aspect of political, technocratic, participative, top down and bottom up approach.
Community facilitated by government and NGO for participating in the cultural planning of Yogyakarta. Available websites for the planning are e-participatory planning, e-monitoring and eevaluation.

\section{ACKNOWLEDGEMENTS}

Thank you for Dean and Head of Study Program, Department of National Developmet Planning, Department of Regional Development Planning, Cultural Agency, Joglo Forum, Java Reconstruction Fund, and Kotagede community.

\section{REFERENCES}

[1]. Adrisijanti, I. 2006. Islam as an Indonesian Cultural Roots. Mimeo. Coaching for Special Region of Yogyakarta, Central and East Java Regional History. BPSNT of Yogyakarta. 1114 Juli 2006, 1 and 8-9.

[2]. Bandarin, F. and R. V. Oers. 2012. Historic urban landscape. Wiley Blackwell Publishing. West Sussex, 5-17.

[3]. Harrison, R. 2013. Heritage, critical approach. Routledge. New York, 27 and 31. 
[4]. Sudikno, A. 2007. Preservation of ancient buildings as assets of nation cultural history. Mimeo. Inauguration Speech of Professor Position in History and Architecture Preservation Field. Faculty of Engineering, University of Brawijaya, Malang. $3^{\text {rd }}$ December 2007, 6-12.

[5]. Buwono X, S. S. H. 2007. Reassembling our Indonesian. Gramedia Pustaka Utama. Yogyakarta, 4-28.

[6]. Bandarin, F., J. Hosagrahar, and F. S. Albernaz. 2011. Why development needs culture. Journal of Cultural Heritage Management and Sustainable Development 1(1), 15-25.

[7]. Cano, G. A., A. Garzon and G. Poussin (Eds). 2005. Cultural, trade and globalization. Kanisius Publisher. Yogyakarta, 15-20.

[8]. Nayati, W., R. B. Santoso, Y. S. Suwito, K. Jatiningrat. 2006. Action plan of Yogyakarta Special Region stabilization as famous cultural center. Center of Culture Study, Gadjah Mada University and Department of Regional Developmet Planning Yogyakarta, Yogyakarta, 1.

[9]. Budihardjo, E. (Ed). 1997. Cultural heritage in Indonesia. Gadjah Mada University Press. Yogyakarta, 8-9.

[10]. Kidokoro, T., J. Okata, S. Matsumura, N. Shima (Eds). 2008. Vulnerable cities, realities, innovations, and strategies. Springer. Japan, 241-253.

[11]. Sumpeno, W. 2011. Integrated Village Planning. Read. Banda Aceh, 49.

[12]. Branch, M. 1995. Comprehensive city planning. Bambang, H. W. (Transl.) Gadjah Mada University Press. Yogyakarta, 90.

[13]. Muliono, M., G. Limberg, P. Minnigh, A. Mulyana, Y. Indriatmoko, N. A. Utomo, Saparuddin, Hamzah, R. Iwan, and E. Purwanto. 2010. Hacking the deadlock: concept and guide of special zone development for National Park in Indonesia. CIFOR. Bogor, 7.

[14]. Teutonico, J. M. and P. Gaetano (Eds). 2002. Proceedings of Management Planning for Archaeological Sites. The Getty Conservation Intitute. Los Angeles, 25.

[15]. Haris, A. 2003. The sweat disbursement and development tap. Pustaka Pelajar. Yogyakarta, 139.

[16]. Adrisijanti, I. 2005. Kotagede: An archaeological perspective of a capital city in Java in the $17^{\text {th }}$ century. Humaniora 17 (2), 125-134.
[17]. World Monument Fund. 2008. Kotagede Heritage District, 2008 world monument watch list of 100 most endangered sites. http://www.wmf.org. Accessed July $14^{\text {th }}$, 2014.

[18]. Java Reconstruction Fund. 2009. Proceeding of stakeholders meeting for Kotagede preservation and management program syncronization. Java Reconstruction Fund. Kotagede, Yogyakarta.

[19]. Djunaedi, A. 2012. City and regional planning process. Gadjah Mada University Press. Yogyakarta.

[20]. Nugroho, R. and R. R. Wrihatnolo. 2011. Development planning management. PT Elex Media Komputindo, Gramedia. Jakarta.

[21]. Tjokroamidjojo, B. 1995. Development Planning. PT Toko Gunung Agung. Jakarta.

[22]. Conyers, D. 1991. An introduction to social planning in the third world. Susetiawan (Transl). Gadjah Mada University Press. Yogyakarta.

[23]. Frederickson, G., K. B. Smith, C. W. Larimer, and M. J. Licari. 2012. The public administration theory primer. Westview Press. Colorado, 57 and 102.

[24]. Miles, M. B. and Huberman, M. 1992. Qualitative Data Analysis. Rohidi, T. R. (TransI). UI Press. Jakarta.

[25]. Kutoyo, M. S. 1977. History of Yogyakarta Special Region. Cultural Values Study and Development Project. Central Directorate of History and Traditional Values. Jakarta.

[26]. Regional Regulation of Yogyakarta Special Region No. 4 of 2011 on Yogyakarta Values. Yogyakarta, 4.

[27]. Regional Regulation of Yogyakarta Special Region No. 6 of 2012 on Cultural Heritage Conservation.

[28]. Java Reconstruction Fund and Joglo Forum. 2011. Kotagede Heritage District management and conservation plan. Yogyakarta, I-1.

[29]. Cultural Agency. 2010. Integrated revitalization master plan of Kotagede, Yogyakarta, 1-7.

[30]. Government of Yogyakarta Special Region. Local Government Work Plan of 2014. 2014. Regional Government of Yogyakarta Special Region. Yogyakarta, 13-14.

[31]. Kotagede Community. 2008. Planning of Settlement Structuring-Heritage Program, Yogyakarta. 